\title{
DEKSMEDETOMIDINO EFEKTYVUMAS MINIMALIAI INVAZINĖS VAIKŲ İDUBUSIOS KRŪTINĖS KOREKCIJOS POOPERACINIO SKAUSMO MALŠINIMUI
}

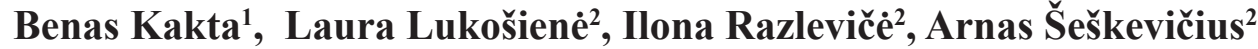 \\ ${ }^{1}$ Lietuvos sveikatos mokslu universiteto Medicinos akademijos Medicinos fakultetas, \\ ${ }^{2}$ Lietuvos sveikatos mokslu universiteto Medicinos akademijos Anesteziologijos klinika
}

Raktažodžiai: deksmedetomidinas, pooperacinio skausmo valdymas, įdubusi krūtinè, vaikas, paciento kontroliuojama analgezija.

\section{Santrauka}

Tikslas. Ivertinti deksmedetomidino, kaip papildomo skausmą malšinančio komponento efektyvumą, valdyti minimaliai invazinès vaikų krūtinès įdubos korekcijos pooperacinị skausmą.

Metodika. Atliktas stebimasis atvejo - kontrolès tyrimas, ì kurị itrauktas 51 pacientas.

Kontrolinę grupę sudarè pacientai, kuriems pooperacinio skausmo malšinimui buvo skirtas morfinas paciento kontroliuojamos analgezijos (PKA) būdu (PKA grupè). Pacientai, kuriems kartu su morfinu PKA būdu buvo skirta tęstinè deksmedetomidino infuzija, priskirti atvejo grupei (PKA DEX grupè). Atlikta narkozès lapų, operacijų ir PKA protokolų, ligos istorijos duomenų analizè. Analizuoti kintamieji - skausmo intensyvumas pagal vaizdinès analogijos skalę (VAS), morfino suvartojimas bei morfino šalutiniai reiškiniai tarp grupių.

Rezultatai. PKA grupę sudare $30(58,8 \%)$ pacientų, DEX PKA - $21(41,2 \%)$ pacientas. VAS balai buvo mažesni DEX PKA grupeje iškart po operacijos bei praejjus 9 ir 12 valandų $(\mathrm{p}<0,05)$. DEX PKA grupeje suminis morfino suvartojimas per pirmąsias 12 val. po operacijos $\mathrm{mg} /$ $\mathrm{kg}$ buvo mažesnis, lyginant su PKA grupe, o skirtumas buvo statistiškai reikšmingas $(\mathrm{p}<0,05)$. Morfino šalutinių reiškinių dažnis statistiškai reikšmingai tarp grupių nesiskyre $(\mathrm{p}>0,05)$. DEX PKA grupés pacientams stebètas didesnis sedacijos laipsnis iškart po operacijos, bei praejus 3, 6 ir 12 valandu po operacijos $(\mathrm{p}<0,05)$.

Išvados. DEX PKA grupeje stebèti mažesni VAS balai iškart po operacijos, praejjus 9 ir 12 val. po operacijos, mažesnis suminis morfino suvartojimas buvo statistiškai reikšmingas per pirmąsias 12 val. po operacijos. Morfino šalutinio poveikio dažnis tarp tiriamujjų grupių nesiskyrè, DEX PKA grupeje stebètas didesnis sedacijos laipsnis, tačiau jis buvo kliniškai nereikšmingas.

\section{Ivadas}

Igimtos krūtinès sienos deformacijos, kurių korekcijai reikalingas chirurginis gydymas, apima visą spektrą skeleto raumenų sistemos morfologinių sutrikimų. Didžiausią dalį visų igimtų krūtinès sienos deformacijų sudaro įdubusi krūtinè (pectus excavatum), kurios dažnis yra apie 1/400 gimusiujų [1].

Minimaliai invazinè įdubusios krūtinès korekcijos metodika, kitaip žinoma kaip Nuss operacija, yra plačiai paplitusi procedūra vaikų chirurgijoje. Operacija atliekama taikant videotorakoskopinę kontrolę, todèl operacijos metodika yra minimaliai invazinio pobūdžio, t. y. maži pjūviai, mažesnè audinių trauma, tačiau specialios plokštelès įterpimas sukelia pooperacinę krūtinès ląstos remodeliaciją ir labai stiprų pooperacinį skausmą $[2,3]$. Kai kurių autorių teigimu, skoliozès ir įdubusios krūtinès chirurginès korekcijos operacijos sukelia bene stipriausią vaikų pooperacinį skausmą, kurio malšinimui reikia kurti atskirus skausmo malšinimo protokolus $[2,3]$. Dominuoja dvi pagrindinès skausmo valdymo po minimaliai invazinès įdubusios krūtinès korekcijos operacijų strategijos: sisteminè analgezija opioidais PKA būdu ir įvairios vietinių anestetikų metodikos $[4,5]$. Dél didelio skausmo intensyvumo, taikant sisteminị skausmo malšinimą opioidais, reikalingos didelès dozès, ypač ankstyvuoju pooperaciniu laikotarpiu [2,3]. Didinant opioidų dozes, didèja skausmą malšinantis efektas, bet kartu didejja ir nepageidaujamas šalutinis poveikis: kvėpavimo depresija, sedacija, pykinimas, vėmimas, šlapinimosi sutrikimai [2].

Lietuvos sveikatos mokslų universiteto Kauno kliniku (LSMU KK) Vaikų chirurgijos klinikoje minimaliai invazinès įdubusios krūtinès korekcijos operacijos atliekamos nuo 2003 metų. Pooperacinio skausmo valdymui taikoma 
daugiakomponente strategija, apimanti sisteminį skausmo malšinimą morfinu PKA būdu, nesteroidinius vaistus nuo uždegimo (NVNU), acetaminofeną, taip pat ir kartu atliekamą regioninę - tarpšonkaulinių nervų blokadą (TNB).

Regioninès blokados su vietiniais anestetikais leidžia efektyviai sumažinti opioidų suvartojimą, jų šalutinius reiškinius ir ženkliai pagerinti pooperacinio skausmo valdymo kokybę [6,7], tačiau išanalizavę medicininès literatūros duomenis ir, remdamiesi ilgamete klinikine praktika, ieškojome naujų sisteminès anlgezijos komponetų vaikams, kuriems atliekamos Nuss operacijos.

Deksmedetomidinas, kaip papildoma daugiakomponenčio skausmo malšinimo dalis, sulaukia vis daugiau dėmesio viso pasaulio anesteziologų klinikinejje praktikoje. Tai yra selektyvus alfa-2 adrenoreceptorių agonistas, kuris aktyvina presinapsinius ir postsinapsinius receptorius, mažina simpatinès nervų sistemos aktyvumą. Nugaros smegenų užpakalinių ragų neuronuose deksmedetomidinas slopina skausmini signalą stiprinančių glutamato ir P substancijos išskyrimą ir taip slopina kylančiuosius nocicepcinius signalus. Tai yra pagrindiniai deksmedetomidino, kaip analgetinio adjuvanto, veikimo mechanizmai [8]. Poveikis širdies ir kraujagyslių sistemai bei sedacija pasireiškia dèl veikimo $i$ tuos pačius alfa- 2 adrenoreceptorius, esančius skirtingose vietose: pailgujų smegenų vazomotoriniame centre ir dorsaliniame klajoklio nervo branduolyje. Didelis selektyvumas ir lipofiliškumas nulemia šio medikamento gebejimą sukelti sedaciją, analgeziją ir anksiolizę, nesukeldamas kvèpavimo centro slopinimo ar kliniškai reikšmingų kardiovaskulinių ivvykių [8].

Pastaraisiais metais medicinineje literatūroje atsiranda vis daugiau tyrimų ir duomenų apie deksmedetomidino pritaikymą intensyviosios terapijos skyriuose, operacinèse, atliekant invazines ir tiriamąsias procedūras ne operacinèse, malšinant suaugusiujjų pooperacinị skausmą [9-13]. Nors vaikų intensyviojoje terapijoje ir anesteziologijoje šis medikamentas gerai žinomas ir sèkmingai taikomas minètose aplinkose [14,15], bet tyrimų apie jo efektyvumą malšinant pooperacinị skausmą vis dar trūksta.

Tyrimo tikslas - įvertinti deksmedetomidino, kaip papildomo skausmą malšinančio komponento, efektyvumą valdyti minimaliai invazinès vaikų įdubusios krūtinès korekcijos pooperacinị skausmą.

\section{Tyrimo medžiaga ir metodai}

I tyrimą įtraukti LSMU KK vaikų chirurgijos klinikos pacientai, kuriems 2012-2020 m. buvo atliekamos iqdubusios krūtinès ląstos korekcijos operacijos minimaliai invaziniu būdu. Išanalizuoti pacientų ligos istorijų duomenys, narkozès lapai, operacijų ir PKA protokolai. Tyrimui atlikti gautas
Bioetikos centro leidimas Nr. BEC-MF-173. Tyrimas atliktas taikant stebimaji atvejo - kontrolès tyrimo modelị.

I tyrimą itrauktas 51 pacientas. Kontrolinei grupei (PKA grupe) priskirti pacientai, kurių pooperacinio skausmo valdymui taikytas morfinas PKA būdu, NVNU, acetaminofenas, bei atlikta TNB (30 pacientų). Atvejo grupei (DEX PKA grupè) priskirti pacientai, kuriems papildomai skirta deksmedetomidino tęstinè infuzija (21 pacientas).

Anestezijos eiga abiejų grupių pacientams nesiskyrè. Atvykus ị operacinę pradèta gyvybinių funkcijų stebėsena ir infuzoterapija. Anestezijos indukcijai intraveniškai skirta: fentanilis, propofolis ir rokuroniumas. Anestezijos indukcijos metu taikyta pooperacinio pykinimo ir vėmimo (PPV) profilaktika ondansetronu ir deksametazonu. Po trachejos intubacijos, anestezijos palaikymui skirtas inhaliacinis anestetikas sevofluranas. Anestezijos metu taikyta standartinè stebėsena: deguonies koncentracija kvèpuojamajame mišinyje, pulsoksimetrija, kapnografija, širdies susitraukimų dažnis, neinvazinis kraujospūdis, elektrokardiograma, šerdinè kūno temperatūra. Anestezijos eigos duomenys buvo registruojami narkozès lape. Iškart po anestezijos, indukcijos ir trachèjos intubacijos visiems pacientams buvo atlikta vienkartinè abipuse TNB su vietinio anestetiko levobupivakaino ir epinefrino tirpalu, apimanti plokštelès įterpimo vietos tarpšonkaulinį tarpą ir po du tarpus aukščiau ir žemiau šios vietos. Nuss operacija buvo atliekama tos pačios patyrusių chirurgų komandos.

Sisteminis skausmo malšinimas pradètas intraoperaciniu laikotarpiu pagal iš anksto numatytą planą: ketoprofenas po anestezijos indukcijos ir trachejos intubacijos, acetaminofenas pradejjus užsiūti chirurginius pjūvius ir morfinas PKA būdu iškart po ekstubacijos. PKA pompos nustatymai buvo vienodi visiems pacientams. DEX PKA grupés pacientams kartu su morfinu buvo pradèta ir tęstinè deksmedetomidino infuzija $0,1-0,2 \mu \mathrm{g} / \mathrm{kg} / \mathrm{val}$. greičiu.

Pirmas 48 val. po operacijos, abiejų grupių pacientams, kartu su morfinu PKA būdu ir deksmedetomidino infuzija, intraveniškai buvo skiriami NVNU ir acetaminofenas nustatytomis valandomis. Kitų skausmą malšinančių medikamentų (ketorolako, ibuprofeno) skyrimas buvo numatytas skausmo proveržiu gydymui pagal individualų poreikį. Pykinimo ir vėmimo gydymas ondansetronu ir metoklopramidu taip pat buvo numatytas pagal individualų poreikị.

Abiejų grupių pacientų stebėsena buvo vykdoma 24-48 val. po operacijos. Pirmą pooperacinę parą - Vaikų intensyviosios terapijos skyriuje, o vèlesniu laikotarpiu tęsiama Vaikų chirurgijos skyriuje. Gydymo morfinu PKA būdu pacientų stebejjimo protokole kas 3 val. buvo registruojama: suvartotas morfino kiekis ml per 3 val., žodžiu nusakomas skausmo laipsnis ramybejje pagal VAS skalę, kvėpavimo dažnis kartais per min., sedacija 4 balų skalejje, pykinimas 
(vėmimas), šlapinimosi sutrikimai. Sedacija buvo vertinama 4 balų skalejje: 0 - budrus, žvalus; 1 snaudžia, atsimerkia pašaukus vardu; 2 - miega, atsimerkia ị fizinị dirgiklį; 3 - gilus miegas, negalima pažadinti.

Tyrimo duomenys apdoroti naudojantis SPSS Statistics 25.0. Kokybinių požymių reikšmių pasiskirstymo homogeniškumui ịvertinti lyginamosiose grupèse buvo naudojamas chi kvadrato $\left(\chi^{2}\right)$ kriterijus. Kiekybinių požymių reikšmės grupėse buvo lyginamos taikant Mann-Whitney kriterijų dviems nepriklausomoms imtims, nes kintamieji buvo pasiskirstę ne pagal normalumo dèsnį. Kintamiesiems, turintiems normaluji skirstinị, palyginti naudotas Student t kriterijus. Rezultatai aprašyti pateikiant vidurkius ir standartinius nuokrypius arba medianas ir pirmaji bei trečiajị kvartilius (Q1-Q3). Rezultatai laikyti statistiškai reikšmingais, kai $\mathrm{p}<0,05$.

\section{Tyrimo rezultatai}

Bendra tiriamųjų charakteristika. Tyrime dalyvavo 51 pacientas, kurių amžius svyravo nuo 7 iki 18 metų. Vidutinis pacientų amžius ir svoris abiejose grupèse buvo panašus. Tarp tiriamujų buvo 43 (83,4 proc.) berniukai ir 8 (15,7 proc.) mergaitès. Tiriamųjų pasiskirstymas pagal lytị ir ASA klasę grupèse taip pat buvo panašus. Demografiniai duomenys pateikti 1 lentelëje.

Pooperacinio skausmo intensyvumo vertinimas. Pooperacinio skausmo intensyvumas buvo vertintas VAS balų medianomis.

Iškart po operacijos VAS balų mediana buvo mažesnè DEX PKA grupeje. Skirtumas tarp grupių buvo statistiškai reikšmingas $(\mathrm{p}<0,05)$. Praejus 9 ir 12 val. po operacijos taip pat stebèta mažesnè VAS balų mediana, skirtumas buvo statistiškai reikšmingas $(\mathrm{p}<0,05)$. Kituose laiko intervaluose

1 lentelè. Tirtos imties chakteristika.

$n$-atveju skaičius, $V$-vidurkis, $S N$ - standartinis nuokrypis, $M$ - mediana, Q1-Q3 pirmas ir trečias kvartiliai; p reikšmé, remiantis parametriniu Student t testu dviem nepriklausomoms imtims, ${ }^{a}$ p reikšmé, remiantis chi-kvadrato nepriklausomumo testu, ${ }^{b}$ p reikšmé, remiantis Mann-Whitney testu.

\begin{tabular}{|l|l|l|l|}
\hline Charakteristika & $\begin{array}{l}\text { PKA grupe } \\
(\mathbf{n = 3 0})\end{array}$ & $\begin{array}{l}\text { PKA DEX } \\
\text { grupe் }(\mathbf{n}=\mathbf{2 1})\end{array}$ & $\begin{array}{l}\text { p } \\
\text { reikšmé }\end{array}$ \\
\hline $\begin{array}{l}\text { Amžius } \\
\text { (metais, V(SN)) }\end{array}$ & $14,4(2,7)$ & $14,6(1,9)$ & 0,710 \\
\hline $\begin{array}{l}\text { Berniukai/mergaitės, } \\
\text { n (proc.) }\end{array}$ & $\begin{array}{l}27(90,0) / \\
3(10,0)\end{array}$ & $\begin{array}{l}16(76,2) / \\
5(23,8)\end{array}$ & $0,249^{\mathrm{a}}$ \\
\hline Svorio (kg, V(SN)) & $56,0(14,2)$ & $57,3(12,2)$ & 0,737 \\
\hline ASA klasė M[Q1-Q3] & $1[1-2]$ & $2[1-2]$ & $0,691^{\mathrm{b}}$ \\
\hline
\end{tabular}

statistiškai reikšmingo skirtumo tarp grupių nestebèta. Duomenys pateikti 1 paveiksle.

Morfino suvartojimo palyginimas tarp grupių. PKA būdu suvartoto morfino suminè dozé pirmąsias 12 val. po operacijos buvo didesnè PKA grupés pacientams, lyginant su DEX PKA grupe. Skirtumas tarp grupių buvo statistiškai reikšmingas $(\mathrm{p}<0,05)$. Duomenys pateikti 2 lentelëje.

Morfino šalutinio poveikio palyginimas tarp grupių. Morfino šalutiniai reiškiniai - pykinimas (vėmimas), šlapimo

2 lentelè. Suminio morfino suvartojimo 12 valandų intervalais palyginimas tarp grupių.

Morfino kiekis $\mathrm{mg} / \mathrm{kg}$ nurodytas kaip mediana [Q1-Q3].

\begin{tabular}{|c|c|c|c|}
\hline \multirow{2}{*}{$\begin{array}{l}\text { Pooperacinis } \\
\text { laikotarpis, } \\
\text { valandos po } \\
\text { operacijos }\end{array}$} & \multicolumn{2}{|c|}{ Suminis morfino suvartojimas } & \multirow{2}{*}{$\begin{array}{l}\text { p } \\
\text { reiǩš- } \\
\text { mé }\end{array}$} \\
\hline & PKA grupè & & \\
\hline & & & \\
\hline & & & \\
\hline-24 suminis & 0,486 & 0,373 & 0,3 \\
\hline
\end{tabular}

3 lentelè. Morfino šalutinių reiškinių pasireiškimo dažnis tarp grupių.

$n(\%)$ - pacientu skaičius ir ju procentiné dalis grupejje.

\begin{tabular}{|l|l|l|l|}
\hline \multirow{2}{*}{ Šalutinis reiškinys } & \multicolumn{2}{|l|}{ Dažnis, n(\%) } & \multirow{2}{*}{ p reikšmė } \\
\cline { 2 - 4 } & PKA DEX & PKA & \\
\hline Pykinimas (vėmimas) & $7(33,3 \%)$ & $11(36,7 \%)$ & 0,806 \\
\hline Šlapimo susilaikymas & $6(28,6 \%)$ & $4(13,3 \%)$ & 0,177 \\
\hline
\end{tabular}


susilaikymas statistiškai reikšmingai tarp grupių nesiskyrè ( $p>0,05$ ). Duomenys pateikiami 3 lentelèje.

DEX PKA grupès pacientams stebètas didesnis sedacijos laipsnis iškart po operacijos, praejjus 3, 6 ir 12 valandų po operacijos $(p<0,05)$. Šiais laiko intervalais sedacijos laipsnis neviršijo 1 balo. Duomenys pateikti 4 lentelejje.

\section{Diskusija}

Daugiakomponentès pooperacinio skausmo valdymo strategijos esmè - keleto skausmą malšinančių priemonių, veikiančių skausmo mechanizmus skirtingais skausmo neurosensorinès grandinès lygiais, skyrimas kartu. Nustatyta, kad dèl sinergistinio suminio poveikio, kartu skiriant opioidus, NVNU, acetaminofeną ir vietinius anestetikus, sustiprejja antinocicepcinis poveikis, sumažeja atskirų medikamentų dozès ir nepageidautinas šalutinis poveikis $[16,17]$. Deksmedetomidino gebėjimas sukelti analgeziją ir anksiolizę, nesukeliant kvẻpavimo centro slopinimo ar reikšmingų kardiovaskulinių ịvykių, turi neabejotiną potencialą pagerinti daugiakomponenčio pooperacinio skausmo malšinimo kokybę [8].

Optimalaus pooperacinio skausmo valdymo metodo pasirinkimas vaikams, kuriems atliekamos minimaliai invazinès įdubusios krūtinès korekcijos operacijos, tiek klinikinèje praktikoje, tiek medicininejje literatūroje išlieka aktualus ir kelia nemažai susidomejjimo [18].

Tyrimų duomenys rodo, kad skausmo intensyvumas po Nuss operacijų yra stiprus ir siekia $8-10$ balų pagal VAS, todèl ji galima prilyginti skausmui po jaunatvinès idiopatinès skoliozès chirurginès korekcijos. J. Jones atliktame retrospektyviniame tyrime gauti duomenys, kad deksmedetomidino naudojimas kartu su PKA būdu skiriamais opioidais sumažino skausmo balus per pirmąsias 24 val. po skoliozès korekcijos operacijos, lyginant su PKA opioidais, nenaudojant deksmedetomidino [19]. Mūsų tyrimo rezultatai parodé, kad DEX PKA grupejje pirmas 24 val. po operacijos stebeta

4 lentelè. Sedacijos laipsnio palyginimas tarp grupių.

Sedacija buvo vertinamata 4 balu skalëje: 0 - budrus, žvalus; 1 - snaudžia, atsimerkia pašaukus vardu; 2 - miega, atsimerkia i fizini stimula, 3 - gilus miegas, negalima pažadinti. Sedacijos laipsnis nurodytas kaip mediana [Q1-Q3].

\begin{tabular}{|l|c|c|c|}
\hline \multirow{2}{*}{$\begin{array}{l}\text { Laikas po opera- } \\
\text { cijos, val. }\end{array}$} & \multicolumn{2}{|c|}{ Sedacijos laipsnis } & p reikšmè \\
\cline { 2 - 4 } & PKA grupe & DEX PKA grupe & \\
\hline Iškart po operacijos & $0[0-1]$ & $1[0,5-1]$ & $\mathbf{0 , 0 0 6}$ \\
\hline 3 & $0[0-1]$ & $1[0-1]$ & $\mathbf{0 , 0 2 3}$ \\
\hline 6 & $0[0-1]$ & $1[0-1]$ & $\mathbf{0 , 0 5}$ \\
\hline 9 & $0[0-1]$ & $1[0-1,5]$ & 0,053 \\
\hline 12 & $1[0-1]$ & $1[1-2]$ & $\mathbf{0 , 0 1}$ \\
\hline 15 & $1[0,75-2]$ & $1[1-2]$ & 0,144 \\
\hline 18 & $1[0,75-2]$ & $1[0,5-1]$ & 0,411 \\
\hline 21 & $0[0-1]$ & $1[0-1]$ & 0,102 \\
\hline 24 & $0[0-0,25]$ & $0[0-1]$ & 0,388 \\
\hline
\end{tabular}

mažesnių skausmo balų tendencija, tačiau statistiškai reikšmingas skirtumas gautas tik iškart po operacijos ir praejus 9 ir 12 val. po operacijos.

Opioidai pasižymi stipriu skausmą malšinančiu poveikiu, kuris yra tiesiogiai priklausomas nuo dozès - didinant dozę poveikis stipreja, bet dideja nepageidaujami šalutiniai reiškiniai. Tai riboja tolimesnị vaisto dozès didinimą. Opioidų suvartojimo mažinimas yra viena iš svarbiausių multimodalinio skausmo strategijos tikslų. Suminès PKA būdu suvartoto morfino dozès buvo vienas iš svarbiausių mūsų atlikto tyrimo kintamuju. Morfino dozavimas PKA būdu buvo atliekamas pagal iš anksto numatytą protokolą. Tyrimo rezultatai parodè, kad DEX PKA grupeje morfino suvartojimas $\mathrm{mg} / \mathrm{kg}$ buvo mažesnis lyginant su PKA grupe. Panašius rezultatus parode ir Hauber atliktas dvigubai aklas atsitiktinių imčių placebo kontroliuojamas tyrimas su vaikais, kuriems buvo atliekama tonzilektomija. Autoriai nustate, kad opioidų poreikis, skiriant deksmedetomidiną, buvo ženkliai mažesnis, lyginant su placebo grupe -48 ir 73 proc. atitinkamai [20]. A. Tsiotou pateike duomenis, kad po tonzilektomijos deksmedetomidino grupeje, skiriant 20 proc. mažesnę nalbufino dozę, skausmo balai nesiskyré nuo kontrolinès grupès [21].

Opioidų šalutinis poveikis tiesiogiai veikia pooperacinio skausmo malšinimo kokybę, pacientų pasitenkinimą, stacionarinio gydymo trukmę ir ekonominius gydymo aspektus. Tyrimai rodo, kad didžiausią diskomfortą gydymo opioidais metu tiek pacientams, tiek jų tèvams sukelia tokie šalutiniai reiškiniai kaip pykinimas (vėmimas), sedacija, niežulys ir šlapinimosi sutrikimai $[22,23]$. Galimos pooperacinio pykinimo (vėmimo) mažinimo strategijos apima profilaktiką antiemetikais ir daugiakomponentinị skausmo malšinimą, siekiant sumažinti suvartojamų opioidų dozes [24]. Duomenys apie tiesioginį deksmedetomidino poveiki pooperacinio pykinimo (vėmimo) dažniui medicininèje literatūroje gana prieštaringi. Keletas tyrimų, atliktų su vaikais, parodè teigiamą deksmedetomidino poveikị mažinant pooperacinio pykinimo ir vėmimo pasireiškimo dažni [25-27]. Kitų autorių duomenimis, šio efekto nebuvo stebèta $[28,29]$. Mūsų atliktame tyrime tiek pooperacinio pykinimo ir vèmimo dažnis, tiek kiti šalutiniai morfino reiškiniai tarp tiriamujų grupių nesiskyrè. Reikalingi tikslesni, aukštos metodologinès kokybès tyrimai, vertinantys deksmedetomidino poveikị pooperacinio pykinimo (vėmimo) dažniui vaikams po skausmingų ir didelès apimties operacijų.

Deksmedetomidinas sukelia sedaciją remodeliuodamas melsvosios dèmès neuronų aktyvumą dvejopu mechanizmu: mažinamas aktyvinančiųjų acetilcholinerginių neuronų aktyvumas bei didinamas slopinančiujų gama-amino sviesto rūgšties neuronų aktyvumas. Dèl šio veikimo mechanizmo deksmedetomidino sukelta sedacija būna panaši ị natūralų 
miegą $[8,30]$. Z. Jia ir bendraautoriai, vertindami deksmedetomidino poveikị vaikų pažintinėms funkcijoms pooperaciniu periodu, nustatè, kad deksmedetomidino grupèje sedacija buvo nežymiai didesnè, nei placebo grupejje [28]. Panašūs rezultatai stebimi ir N. Kim atlikame tyrime, kur skiriant deksmedetomidiną pacientai buvo labiau seduoti atvykimo i poanestetinę palatą metu ir 30 minučių po to [31]. Mūsų tyrimas taip pat parode, kad DEX PKA grupèje sedacija buvo didesnè iškart po operacijos bei praejus 3, 6 ir 12 valandu po operacijos, tačiau kliniškai vertinant, daugumai pacientų sedacija buvo negili - pacientai snaudžiantys, atsimerkiantys pašaukus vardu. Toks sedacijos lygis leidžia daryti prielaidą, kad pacientai jautèsi pakankamai gerai, skausmas buvo toleruotinose ribose ir šį deksmedetomidino efektą galètume laikyti teigiamu ankstyvojo pooperacinio laikotarpio veiksniu [32]. Tokios išvados formulavimui mūsų duomenų nepakanka, pagrindimui reikalingi tolimesni šios krypties bei pacientu pasitenkinimo ankstyvuoju pooperaciniu tyrimai.

Medicininejje literatūroje atsiranda vis daugiau duomenų apie papildomą deksmedetomidino skyrimą, siekiant sumažinti opioidinių analgetikių poreikị ir suvartojimą, tačiau dauguma šių tyrimų, atliktų su vaikais, analizuoja intraoperacinį deksmedetomidino skyrimą. Nors deksmedetomidino skyrimo nauda medicinineje literatūroje atspindi teigiamas pooperacinio skausmo valdymo tendencijas, reikalingi tolimesni tyrimai, lyginantys intraoperacinio ir tęstinio šio preparato skyrimo privalumus ir skirtumus, optimalių dozių parinkimą.

\section{Išvados}

1. DEX PKA grupejje ankstyvuoju pooperaciniu laikotarpiu stebėta mažesnių skausmo balų tendencija, statistiškai reikšmingas skirtumas gautas iškart po operacijos, praejjus 9 ir 12 val. po operacijos.

2. Morfino suvartojimas buvo mažesnis pirmąsias 12 val. po operacijos DEX PKA grupeje. Morfino šalutinių reiškinių dažnis tarp grupių nesiskyrè.

3. DEX PKA grupeje stebètas didesnis sedacijos laipsnis, tačiau jis nebuvo kliniškai reikšmingas. Reikalingi tolimesni deksmedetomidino, kaip pooperacinio skausmo valdymo papildomo komponento, efektyvumo tyrimai.

\section{Literatūra}

1. Cobben JM, Oostra RJ, van Dijk FS. Pectus excavatum and carinatum. European Journal of Medical Genetics 2014;57(8):414-7. https://doi.org/10.1016/j.ejmg.2014.04.017

2. Rugyte DC, Kilda A, Karbonskiene A, Barauskas V. Systemic postoperative pain management following minimally invasive pectus excavatum repair in children and adolescents: a retrospective comparison of intravenous patient-controlled analgesia and continuous infusion with morphine. Pediatric Surgery International 2010;26(7):665-9.

https://doi.org/10.1007/s00383-010-2619-0

3. Umuroglu T, Bostanci K, Thomas DT, Yuksel M, Yilmaz Gogus F. Perioperative anesthetic and surgical complications of the nuss procedure. Journal Cardiothoracic Vascular Anesthesia 2013;27(3):436-40.

https://doi.org/10.1053/j.jvca.2012.10.016

4. Man JY, Gurnaney HG, Dubow SR, DiMaggio TJ, Kroeplin GR, Adzick NS, et al. A retrospective comparison of thoracic epidural infusion and multimodal analgesia protocol for pain management following the minimally invasive repair of pectus excavatum. Paediatric Anaesthesia 2017;27(12):1227-34.

https://doi.org/10.1111/pan.13264

5. Lukosiene L, Macas A, Trepenaitis D, Kalibatiene L, Malcius D, Barauskas V. Single shot intercostal block for pain management in pediatric patients undergoing the Nuss procedure: a double-blind, randomized, controlled study. Journal Pediatric Surgery 2014;49(12):1753-7.

https://doi.org/10.1016/j.jpedsurg.2014.09.014

6. Lukosiene L, Rugyte DC, Macas A, Kalibatiene L, Malcius D, Barauskas V. Postoperative pain management in pediatric patients undergoing minimally invasive repair of pectus excavatum: the role of intercostal block. Journal Pediatric Surgery 2013:2425-30.

https://doi.org/10.1016/j.jpedsurg.2013.08.016

7. Hall Burton DM, Boretsky KR. A comparison of paravertebral nerve block catheters and thoracic epidural catheters for postoperative analgesia following the Nuss procedure for pectus excavatum repair. Paediatric Anaesthesia 2014;24(5):516-20. https://doi.org/10.1111/pan.12369

8. Nguyen V, Tiemann D, Park E, Salehi A. Alpha-2 agonists. Anesthesiology Clinics 2017;35(2):233-45.

https://doi.org/10.1016/j.anclin.2017.01.009

9. Nie Y, Tu W, Shen X, Yu W, Yu Y, Song X, et al. Dexmedetomidine added to sufentanil patient-controlled intravenous analgesia relieves the postoperative pain after cesarean delivery: a prospective randomized controlled multicenter study. Scientific Reports 2018;8(1):1-11.

https://doi.org/10.1038/s41598-018-27619-3

10. Kim NY, Kwon TD, Bai SJ, Noh SH, Hong JH, Lee H, et al. Effects of dexmedetomidine in combination with fentanyl-based intravenous patient-controlled analgesia on pain attenuation after open gastrectomy in comparison with conventional thoracic epidural and fentanyl-based intravenous patientcontrolled analgesia. International Journal Medical Sciences 2017;14(10):951-60.

https://doi.org/10.7150/ijms.20347 


\section{4}

11. Bielka K, Kuchyn I, Babych V, Martycshenko K, Inozemtsev O. Dexmedetomidine infusion as an analgesic adjuvant during laparoscopic cholecystectomy: a randomized controlled study. BMC Anesthesiology 2018;18(1):4-9. https://doi.org/10.1186/s12871-018-0508-6

12. Uusalo P, Jätinvuori H, Löyttyniemi E, Kosola J, Saari TI. Intranasal low-dose dexmedetomidine reduces postoperative opioid requirement in patients undergoing hip arthroplasty under general anesthesia. Journal Arthroplasty 2019;34(4):686-692.e2. https://doi.org/10.1016/j.arth.2018.12.036

13. Šimonytė L., Razlevičè I., Lukošienè L., Macas A. Deksmedetomodino naudojimas neoperacinèje aplinkoje. Sveikatos mokslai, 2020;30(2):96-9.

https://doi.org/10.35988/sm-hs.2020.050

14. van Hoorn CE, Flint RB, Skowno J, Davies P, Engelhardt $\mathrm{T}$, Lalwani $\mathrm{K}$, et al. Off-label use of dexmedetomidine in paediatric anaesthesiology: an international survey of 791 (paediatric) anaesthesiologists. European Journal Clinical Pharmacology. 2020;

https://doi.org/10.1007/s00228-020-03028-2

15. Sottas CE, Anderson BJ. Dexmedetomidine: the new all-in-one drug in paediatric anaesthesia? Current Opinion in Anaesthesiology 2017;30(4):441-51.

https://doi.org/10.1097/ACO.0000000000000488

16. Hariharan S, Moseley H, Kumar A, Raju S. The effect of preemptive analgesia in postoperative pain relief - a prospective double-blind randomized study. Pain Medicine 2009;10(1):49-53.

https://doi.org/10.1111/j.1526-4637.2008.00547.x

17. Wong I, St John-Green C, Walker SM. Opioid-sparing effects of perioperative paracetamol and nonsteroidal anti-inflammatory drugs (NSAIDs) in children. Paediatric Anaesthesia 2013;23(6):475-95.

https://doi.org/10.1111/pan.12163

18. Singhal NR, Jerman JD. A review of anesthetic considerations and postoperative pain control after the Nuss procedure. Seminars Pediatric Surgery 2018;27(3):156-60.

https://doi.org/10.1053/j.sempedsurg.2018.05.010

19. Jones JS, Cotugno RE, Singhal NR, Soares N, Semenova J, Nebar S, et al. Evaluation of dexmedetomidine and postoperative pain management in patients with adolescent idiopathic scoliosis: conclusions based on a retrospective study at a tertiary pediatric hospital. Pediatric Critical Care Medicine 2014;15(6). https://doi.org/10.1097/PCC.0000000000000119

20. Hauber JA, Davis PJ, Bendel LP, Martyn S v., McCarthy DL, Evans MC, et al. Dexmedetomidine as a rapid bolus for treatment and prophylactic prevention of emergence agitation in anesthetized children. Anesthesia and Analgesia 2015;121(5):1308-15.

https://doi.org/10.1213/ANE.0000000000000931

21. Tsiotou AG, Malisiova A, Kouptsova E, Mavri M, Anagnosto- poulou M, Kalliardou E. Dexmedetomidine for the reduction of emergence delirium in children undergoing tonsillectomy with propofol anesthesia: a double-blind, randomized study. Paediatric Anaesthesia 2018;28(7):632-8.

https://doi.org/10.1111/pan.13397

22. Chabot B, Ferland CE. Inpatient postoperative undesirable side effects of analgesics management: a pediatric patients and parental perspective. Pain Reports 2020;5(5):e845. https://doi.org/10.1097/PR9.0000000000000845

23. Dolin SJ, Cashman JN. Tolerability of acute postoperative pain management: nausea, vomiting, sedation, pruritis, and urinary retention. British Journal Anaesthesia 2005;95:584-91. https://doi.org/10.1093/bja/aei227

24. Kovac AL. Postoperative nausea and vomiting in pediatric patients. Pediatric Drugs 2020;(0123456789). https://doi.org/10.1007/s40272-020-00424-0

25. Song Y, Shim JK, Song JW, Kim EK, Kwak YL. Dexmedetomidine added to an opioid-based analgesic regimen for the prevention of postoperative nausea and vomiting in highly susceptible patients. European Journal Anaesthesiology 2016;33(2):75-83. https://doi.org/10.1097/EJA.0000000000000327

26. Ming S, Xie Y, Du X, Huang H, Fan Y, Liang Q, et al. Effect of dexmedetomidine on perioperative hemodynamics and organ protection in children with congenital heart disease: a randomized controlled trial. Medicine 2021;100(1):e23998. https://doi.org/10.1097/MD.0000000000023998

27. Li H, Zhang L, Shi M, Yang S, Li S, Gao S. Impact of dexmedetomidine on pediatric agitation in the postanesthesia care unit. Journal Perianesthesia Nursing 2018;33(1):53-7. https://doi.org/10.1016/j.jopan.2016.03.005

28. Jia Z, Hao H, Huang M, Ma D, Jia X, Ma B. Influence of dexmedetomidine to cognitive function during recovery period for children with general anesthesia. European Review Medical Pharmacological Sciences 2017;21(5):1106-11.

29. Al-Zaben KR, Qudaisat IY, Alja'Bari AN, Ababneh OA, Yousef AMM, Al-Shudifat AM. The effects of caudal or intravenous dexmedetomidine on postoperative analgesia produced by caudal bupivacaine in children: a randomized controlled double-blinded study. Journal Clinical Anesthesia 2016;33:386-94. https://doi.org/10.1016/j.jclinane.2016.04.049

30. Schwarz LA, Luo L. Organization of the locus coeruleus-norepinephrine system. Current Biology 2015;25(21):R1051-R1056. https://doi.org/10.1016/j.cub.2015.09.039

31. Kim NY, Kim SY, Yoon HJ, Kil HK. Effect of dexmedetomidine on sevoflurane requirements and emergence agitation in children undergoing ambulatory surgery. Yonsei Medical Journal 2014;55(1):209-15. https://doi.org/10.3349/ymj.2014.55.1.209

32. Lerman J. Anxiolysis - by the parent or for the parent? Anesthesiology 2000;92:925-925. https://doi.org/10.1097/00000542-200004000-00005 


\section{POSTOPERATIVE PAIN MANAGEMENT FOR PEDIATRIC PATIENTS UNDERGOING MINIMALLY INVASIVE REPAIR OF PECTUS EXCAVATUM. THE ROLE OF DEXMEDETOMIDINE}

B. Kakta, L. Lukošienė, I. Razlevičè, A. Šeškevičius

Keywords: dexmedetomidine, postoperative pain management, pediatric, pectus excavatum.

Summary

Introduction. Minimally invasive repair of pectus excavatum (Nuss procedure) is intensely painful surgery for children. The aim of this study was to evaluate effects of supplementary continuous dexmedetomidine (DEX) administration on postoperative pain management in children receiving morphine based patient controlled analgesia (PCA) after Nuss procedure.

Methods. We performed a single center case-control study of 51 children who undergone Nuss procedure in Hospital of Lithuanian university of health sciences Kaunas clinics Pediatric surgery department. Patients who received DEX infusion supplementary to PCA were selected as case group (DEX group), while patients who received only PCA were selected as control group. Patients' case records, surgery and PCA protocols were analyzed. Demographic data, pain experience according to visual analogue scale (VAS), morphine consumption and opioid-related side effects were recorded.
Results. 21(41,2\%) patient received DEX, while 30(58,8\%) did not. Pain intensity was lower in DEX group immediately after the surgery, at 9 and 12 hours postoperatively $(p<0,05)$ and less children in DEX group experienced pain during first evaluation $(15,0 \%$ vs $53,3 \%, p=0,006)$. Morphine consumption in DEX group was lower during first 12 hours postoperatively compared to control group $(0,169(0,249)$ and $0,223(0,14) \mathrm{mg} / \mathrm{kg}$ respectively, $\mathrm{p}=0,047)$. Postoperative nausea and vomiting frequency did not differ between two groups $(\mathrm{p}>0,05)$. Sedation scores were higher in DEX group immediately after the surgery, at 3, 6 and 12 hours postoperatively $(\mathrm{p}<0,05)$.

Conclusion. Continuous DEX infusion combined with morphine based PCA results in lower pain scores in children after Nuss procedure. Continuous postoperative DEX infusion reduces postoperative morphine per kilogram of bodyweight consumption for the first 12 hours after surgery. Dexmedetomidine did not affect the occurrence of opioid-induced postoperative nausea and vomiting, although dexmedetomidine provided light sedation which was clinically insignificant.

Correspondence to: laura.lukosiene@kaunoklinikos.lt

Gauta 2021-05-07 